\title{
Survey on Prevalence and Symptomatology of Major Diseases of Onion (Allium cepa L.) in Northern Parts of Karnataka, India
}

\author{
Shilpa R. Koppad ${ }^{1 *}$, S.B. Babaleshwar ${ }^{1}$, P.R. Dharmatti ${ }^{2}$ and Shripad Kulkarni ${ }^{3}$ \\ ${ }^{1}$ SRF, AINRP on Onion and Garlic, Dept. Horticulture, UAS, Dharwad, Karnataka, India \\ ${ }^{2}$ AINRP on Onion and Garlic, Dept. Horticulture, UAS, Dharwad, Karnataka, India \\ ${ }^{3}$ AINRP on Onion and Garlic, Dept. Plant Pathology, UAS, Dharwad, Karnataka, India \\ *Corresponding author
}

\begin{tabular}{|l|}
\hline Ke y w or d s \\
Prevalence, \\
$\begin{array}{l}\text { Diseases, Onion, } \\
\text { Karnataka. }\end{array}$ \\
\hline Article Info \\
\hline $\begin{array}{l}\text { Accepted: } \\
\text { 26 August } 2017 \\
\text { Available Online: } \\
\text { 10 September } 2017\end{array}$ \\
\hline
\end{tabular}

\section{Introduction}

Onion (Allium cepa L.) is one of the most important commercial vegetable crop grown in India. It is popularly called as "Queen of Kitchen" as it is used as food, salad, spice, condiment and in medicine. The presence of volatile oil known as allyl propyl disulphide is account for pungency in onion. Nutritionally fresh onion contains about $86.8 \%$ moisture, $11.6 \%$ carbohydrates, $1.2 \%$ proteins, $0.2-$ $0.5 \%$ calcium, $0.05 \%$ phosphorous and traces of iron, thiamine, riboflavin and ascorbic acid (Anon, 2003).
India ranks second in onion production after China, accounting for 26.8 percent of world area and 19.9 percent of onion production. The area and production of onion in India is about 11.81 metric hectares and189.24 metric tonnes of bulb, respectively, with an average yield of $16 \mathrm{t} \mathrm{ha}^{-1}$ (NHB, 2015). Among states Karnataka ranks second after Maharashtra. In Karnataka, Northeastern dry Zone is the potential area for the production of onion. The major constraints in the production of onion are diseases caused by fungi. Among fungal 
diseases purple blotch (Alternaria porri) which causes heavy loss in onions under field conditions. Losses ranging from 30 to 100 per cent (Priya et. al., 2016), Stemphylium blight (Stemphylium vesicarium) the yield loss due to this disease ranging from 25 to 50 per cent and basal rot (Fusarium oxysporum f.sp. cepae) the yield loss due to basal rot is up to 50 per cent has been recorded in susceptible cultivars, 30 per cent losses during seedling stage and storage loss accounted to 90 per cent (Davis and Reddy, 1983). These are the three diseases bothering onion crop in field as well as in storage. This is due to nonavailability of resistant source, improper cultural operations and environmental factors etc. Losses due to these diseases ranging from 30 to $100 \%$ (Anupama et al., 2014 and Priya et. al., 2016). These diseases are widespread particularly in rainy season or high moisture conditions. Thus, survey and surveillance from the basis is useful for any successful plant protection strategy. Successful plant protection depends upon early detection of the disease severity followed by timely adoption and application of preventive measures (Sudarshan Rao, 1975). However, systematic survey on the distribution and severity in Northern parts of Karnataka is lacking. There is need to undertake systemic survey to identify hot spots for these diseases in Northern parts of Karnataka. Keeping all these aspects in view, the present investigation was undertaken to know the disease severity in Northern parts of Karnataka.

\section{Materials and Methods}

A roving survey was conducted to know the percent disease severity (PDI) and symptomatology of purple blotch, stemphylium blight and basal rot of onion in districts of Northern parts of Karnataka during Kharif 2014-15. When the crop was at physiological maturity, the survey was carried out from onion growing districts viz.,
Dharwad, Gadag, Haveri, Uttar Kannada and Belagavi. The severity of purple blotch and stemphylium blight diseases was recorded using 0-5 scale (Mayee and Datar, 1986), where in the bulbs described as 0 (zero) indicates no infection, 1 indicates 1-10 per cent bulb area infected, 2 indicates 11- 25 per cent bulb area infected, 3 indicates $26-50$ per cent bulb area infected, 4 indicates 51- 75 per cent bulb area infected and 5 indicates $>75$ per cent bulb area infected.

The Disease Severity percentage was calculated using formula proposed by Wheeler (1969).

$$
\begin{gathered}
\text { Disease Severity } \%=\frac{\text { Sum of numerical values }}{\text { Number of plants Observed X }} \\
\text { Maximum Disease rating }
\end{gathered}
$$

The Disease Severity percentage for basal rot was calculated by the formula.

Disease

No. of bulbs showing basal rot symptoms

Severity percentage $=$

Total No. of bulbs observed

During survey variety grown, symptomatology and soil types were also recorded.

\section{Results and Discussion}

The survey results revealed that the diseases were severe in all the five districts surveyed during Kharif 2014-15. The overall disease severity of purple blotch ranged from $32.31 \%$ to $52.58 \%$, stemphylium blight ranged from 21.24 to $54.35 \%$ and basal rot ranged from 7.78 to $12.54 \%$.

The higher severity of purple blotch was noticed in the local variety of Savadatti taluk $(52.58 \%)$ grown in black soil of Belagavi district. The lowest was noticed in Kundagol taluk, Dharwad (32.31\%) in Nasik red variety 
grown in black soil. Similar findings were reported by Srivastava et.al (1994) in their report on state of field disease and insect pest of onion in India indicated that purple blotch incidence was high in both rainy and postrainy season when humidity prevailed.

Chetana (2000) who conduct survey Northern parts of Karnataka during 1999 also reported that incidence of purple blotch of onion was noticed in all districts of Northern Karnataka and recorded highest per cent of disease incidence in Ronihal village (Basavanabagewadi taluk) of Bijapur district and lowest in Wadullur village of Raichur taluk. The symptoms of purple blotch disease were small, water-soaked lesions with white centers that appear usually on older leaves. As the disease progresses, the lesions enlarge (individual lesions can be as long as 1-2 inches) and become purplish with light yellow concentric rings on the margins. As severity increases, leaves turn yellow brown, lose erectness, and wilt.

Table.1 Prevalence of major diseases of onion in Northern Karnataka

\begin{tabular}{|c|c|c|c|c|c|c|c|c|c|}
\hline \multirow{2}{*}{ District } & \multirow{2}{*}{ Taluk } & \multicolumn{3}{|c|}{ Disease severity (\%) } & \multicolumn{3}{|c|}{ Disease intensity (0-5 scale) } & \multirow{2}{*}{$\begin{array}{l}\text { Soil } \\
\text { type }\end{array}$} & \multirow{2}{*}{ Variety } \\
\hline & & PB & SB & BR & PB & SB & BR & & \\
\hline \multirow{4}{*}{ Dharwad } & Kundgol & 32.31 & 30.15 & 10.1 & 2 & 2 & 1 & Black & Nasik Red \\
\hline & Naragund & 34.11 & 44.57 & 12.3 & 2 & 3 & 2 & Black & Nasik Red \\
\hline & Navalgund & 33.02 & 43.52 & 9.09 & 2 & 3 & 1 & Black & Nasik Red \\
\hline & Mean & 33.15 & 39.41 & 10.50 & & & & & \\
\hline \multirow{2}{*}{ Gadag } & Gadag & 51.11 & 21.24 & 8.23 & 3 & 2 & 1 & Black & Bellary local \\
\hline & Mean & 51.11 & 21.24 & 8.23 & & & & & \\
\hline \multirow{3}{*}{ Haveri } & Haveri & 50.18 & 25.1 & 8.12 & 3 & 2 & 1 & Black & Haveri Local \\
\hline & Ranebennur & 38.88 & 23.36 & 10.22 & 2 & 2 & 2 & Black & Haveri Local \\
\hline & Mean & 44.53 & 24.23 & 9.17 & & & & & \\
\hline \multirow{3}{*}{$\begin{array}{l}\text { Uttar } \\
\text { Kannada }\end{array}$} & Kumata & 40.3 & 26.61 & 7.78 & 2 & 2 & 1 & Sandy & Kumta Local \\
\hline & Haliyal & 41.81 & 42.59 & 11.08 & 3 & 3 & 2 & Sandy & Local \\
\hline & Mean & 41.06 & 34.60 & 9.43 & & & & & \\
\hline \multirow{3}{*}{ Belagavi } & Belagavi & 50.01 & 23.14 & 7.81 & 3 & 2 & 1 & Black & Local \\
\hline & Savadatti & 52.58 & 54.35 & 12.54 & 3 & 3 & 2 & Black & Local \\
\hline & Mean & 51.30 & 38.75 & 10.18 & & & & & \\
\hline
\end{tabular}

PB- Purple Blotch SB- Stemphylim Blight, BR- Basal Rot

Similarly, stemphylium blight severity percentage found higher in the local variety of Savadatti taluk $(54.35 \%)$ grown in black soil of Belagavi district and lower percentage found in Gadag taluk $(21.24 \%)$ in bellary local variety grown under back soil. Similarly, Stemphylium blight was more severe in the winter/summer than in the rainy season (incidence 1.3-100\% and intensity 0.04-25.8\%) (Gupta et. al., 1994) (Table 1). Symptoms start as small yellow to tan, watersoaked lesions that develop into elongated spots that turn dark olive brown to black when spores develop. Leaves may be completely blighted as the lesions coalesce. The symptoms of stemphylium leaf blight are easily confused with purple blotch, which is caused by Alternaria porri.

Disease severity percentage of basal rot noticed higher in Savadatti taluk (12.54 \%) in local grown under black soil of Belagavi district and the least percentage noticed in local variety of Kumata taluk belongs to Uttara Kannada district $(7.78 \%)$ contains sandy soils. These findings were coincided 
with Sudhasha et al., (2008) who conducted survey in two districts of Tamil Nadu. They concluded that the basal rot disease was the predominant and severe disease in the onion growing two districts of Tamil Nadu, viz., Coimbatore and Dindigul. In all places, incidence of basal rot was recorded during different stages of the crop growth and highest disease incidence was observed in Pollachi. Entwistle (1990) concluded that, fungus infects the roots or the basal plate of the bulbs. Further, the infection of bulb scales occurs later in the season and most severe losses are found in post-harvest storage. The symptoms of basal rot were initially yellowing of leaves and stunted growth of plant is observed, which later on dry from tip to downwards.

In early stage of infection, the roots of the plants become pink in colour and rotting take place later. In advanced stage, the bulb starts decaying from lower ends and ultimately whole plant dies. Sumner (1995) reported that Fusarium basal rot, caused by Fusarium oxysporum $f$. sp. cepae, is a devastating disease in onion-growing areas worldwide. Beginning from the leaf tips, progressive wilting, yellowing, curving, and eventually dying back symptoms appear on infected plants. The pathogen causes a brownish, watery rot on infected bulbs. The roots eventually rot and become covered with a whitish mycelium. The first above symptoms is a yellowing of leaf blades at the tip.

This yellowing progresses downward to entire leaf blade. Later such leaves shrivel and decay. Infected plants can be pulled easily because they have a retarded root system. Affected roots are dark brown, flattened, hollow, and transparent. The discoloration starts at the outermost layer of the stem plate and extends upward. At later stage, the stem plate tissue become pitted and exhibited a dry rot (Anupama Patil, 2012).

\section{References}

Anonymous, 2003, FAO- Bulletin of Statistics, pp: 38-44.

Anupama M. P., Benagi V. I. Nargund V. B. Patil R. V., and Koti R. V., 2014, Survey of onion basal rot caused by Fusarium oxysporum f. sp. cepae in Karnataka, Karnataka J. Agric. Sci., 27 (2): 245-246.

Chethana, B.S., 2000. Studies on Alternarialeaf blight of onion (Allium cepaL.). M. Sc. (Agri.) Thesis. Uni. Agric. Sci. Dharwad (India).

Entwistle, A. R., 1990, Root diseases. In: Onion and Allied Crops. Ed. Rabinowitch, H. D. and Brewster, J. L., CRC Press, Boca Raton, Fla, pp. 103154.

Mayee, C.D., and Datar, V.V., 1986, Phytopathometry, Technical Bulletin-1. Marathwada Agric. Univ., Parbhani, p.46.

NHB, 2015. Horticultural statistics at a glance. National Horticultural board, New Delhi. p.65

Priya R.U., Arun sataraddi and Darshan S. 2016, Survey for purple blotch of onion (Alternaria porri (Ellis) Cif.) in northern parts of Karnataka, International Journal of Agriculture, Environment and Biotechnology, 9(3): 367-373.

Sharma, S.R., 1986. Effect of fungicidal sprays on purple blotch and bulb yield of onion. Indian Phytopatho 39: 78-82.

Srivastava, P.K., Bharadwaj, B.S. and Gupta, P.P. 1994. Status of field diseases and selected pests of onion in India. Newsletter Nation. Hort. Res. Devel. Found 14(2): 11-14.

Sudarshan Rao, A.N., 1975. Survey, surveillance and forecast in plant protection. Kissan World 2: 43-44.

Sudhasha, S., Usharani, S. and Ravimycin, T., 2008, Surveillance of onion basal rot 
disease incidence caused by Fusarium oxysporum f.sp. cepae and varietal reaction under field condition, Asian $J$. Bio Sci., 3(2): 369-37.

Vinamrata Patilkulkarni, G., 2013. Organic management of purple blotch of onion caused by Alternariaporri (Ellis) cif. $M$. Sc. (Agri.) Thesis. Uni. Agric. Sci. Dharwad. Karnataka (India).

Wheeler, B.E.J., 1969. An introduction to plant diseases. John Wiley and Sons Ltd., London.

\section{How to cite this article:}

Shilpa R. Koppad, S.B. Babaleshwar, P.R. Dharmatti and Shripad Kulkarni. 2017. Survey on Prevalence and Symptomatology of Major Diseases of Onion (Allium cepa L.) in Northern Parts of Karnataka, India. Int.J.Curr.Microbiol.App.Sci. 6(9): 2603-2607. doi: https://doi.org/10.20546/ijcmas.2017.609.320 